\title{
Removal of Arsenite and Arsenate by Indigenous Iron Ores of Pakistan
}

\author{
Zulfiqar Ali Bhatti ${ }^{1}$, Ghulamullah Maitlo*2 ${ }^{2}$ Ghulam Abbas Kandhro ${ }^{3}$ and \\ Khadija Qureshi ${ }^{1}$ \\ ${ }^{1}$ Chemical Engineering Department, Mehran University of Engineering and Technology, Jamshoro, Sindh Pakistan. \\ ${ }^{* 2}$ Chemical Engineering Department, Dawood University of Engineering and Technology, Karachi, Sindh Pakistan. \\ ${ }^{3}$ Department of Basic Sciences, Mathematics and Humanities, Dawood University of Engineering and Technology, \\ Karachi, Sindh, Pakistan. \\ *Corresponding Author Email: metlo2696@yahoo.com \\ Received 29 January 2019, Revised 21 September 2020, Accepted 21 October 2020
}

\begin{abstract}
This study is focusing on the comparative study of arsenite and arsenate adsorption from the water via indigenous iron ores. The Sindh and Punjab provinces of Pakistan are badly affected by Arsenic (As) toxicity as the people are consuming arsenic contaminated groundwater. The aim of this study is to investigate the effect of anions on adsorption of arsenite As(III) and arsenate $\mathrm{As}(\mathrm{V})$. Impact of $\mathrm{pH}$, contact time, adsorbent dose and shaking speed on adsorption of arsenite and arsenate is studied with the two selected iron ores from Hoshi and Shikarap from Balochistan. Hoshi and Shikarap ores exhibited higher As(III) and As (V) adsorption, respectively thus selected for further removal studies. Hoshi iron ore without sodium carbonate yields higher adsorption as compared to the samples with $100 \mathrm{mg} / \mathrm{L}$ and $1000 \mathrm{mg} / \mathrm{L}$ sodium carbonate in both As(III) and As $(V)$. Hoshi ore exhibited the highest adsorption of $85 \%$ for As $(V)$ without sodium phosphate dibasic and $83 \%$ for As(III). Shikarap ore for As(V) adsorbs $75 \%$ without sodium phosphate dibasic and $67 \%$ adsorption for As(III) without sodium phosphate dibasic. Shikarap ore with sodium silicate at $100 \mathrm{mg} / \mathrm{L}$ adsorbs $62 \% \mathrm{As}(\mathrm{III})$ and at $1000 \mathrm{mg} / \mathrm{L}$ adsorb 52\% As(III). Shikarap ore $\mathrm{As}(\mathrm{V})$ adsorption decreases from $75 \%$ without sodium silicate to $70 \%$ at $100 \mathrm{mg} / \mathrm{L}$ and even lower adsorption of $65 \%$ at a higher concentration of $1000 \mathrm{mg} / \mathrm{L}$.
\end{abstract}

Keywords: Arsenite, Arsenate, Adsorption, Iron ores, Anions effect.

\section{Introduction}

Groundwater is usually believed as a harmless supply of drinking water. It is having less number of microbiological pollutants and can be supplied with less or without filtration. Since a long time, Arsenic (As) was investigated as a poisonous element. But it has received more attention as a major drinking water pollutant in recent times by scientists around the world [1]. As is one of the harmful metal found in groundwater, which reduces the safety and quality of drinking water [2]. Drinking As contaminated water may cause many diseases, which include cardiovascular, cancer (skin, liver, bladder), black foot disease, chest infection and hypertension [3]. Adsorption with iron oxyhydroxides has been declared as an efficient and economical method for As treatment from polluted water. Adsorption is an efficient technique as compared to other adsorption i.e. separation using different membranes, separation through ion exchange, electrolysis and bio-reduction methods [4, 5]. There are various As removal methods 
investigated by researchers such as preoxidation of $\mathrm{As}(\mathrm{III})$ to $\mathrm{As}(\mathrm{V})$, adsorption, membrane technology, filtration/ adsorption method and biological As treatment [6]. Hematite $\left(\mathrm{Fe}_{2} \mathrm{O}_{3}\right)$ is a form of iron ore, iron oxide rich and an efficient arsenic removal adsorbent in the adsorption method from contaminated water $[7,8]$. The removal of arsenate from contaminated water by hematite $\left(\mathrm{Fe}_{2} \mathrm{O}_{3}\right)$ and goethite $\mathrm{FeO}(\mathrm{OH})$ ores were investigated by Zhang et al., [9]. Phosphate, sulfate, silicate and carbonate anions interfere the As adsorption on ferric oxides thus reducing the removal efficiency of adsorbents. Different researchers have estimated a variety of different parameters which included concentration of arsenic, $\mathrm{pH}$, shaking time, adsorbent dose, and the effect of anions. $\mathrm{As}(\mathrm{V})$ concentration was reduced from 1 $\mathrm{mg} / \mathrm{L}$ or $\mathrm{mg} / \mathrm{L}$ to less than $0.01 \mathrm{mg} / \mathrm{L}$ considering the $\mathrm{pH}$ limit of 4.5-6.5, the dose of adsorbent was kept $5 \mathrm{~g} / \mathrm{L}$ by the researcher. In another research work more than 309 samples of the river, boring water from district Jamshoro, Sindh, Pakistan were tested for As by atomic absorption spectroscopy (AAS) machine and numerous samples were above the safe limit as per WHO standards [10]. No study yet has been conducted to utilize indigenous iron ores of Pakistan as an adsorbent for the treatment of deadly As contaminated water. Distinct types of iron ores are found in abundant quantity in various parts of Pakistan which can be an efficient and costeffective technology option to solve As contamination issue for common people.

Therefore, this study focuses on the comparative analysis of As contaminants adsorption with the application of native iron ore found in Balochistan, Pakistan. Sequence of experiments were used to find the impact of for variable operating conditions for both $\mathrm{As}(\mathrm{III})$ and $\mathrm{As}(\mathrm{V})$. Impact of chloride $\left(\mathrm{Cl}^{-1}\right)$, sulphate $\left(\mathrm{SO}_{4}{ }^{2-}\right)$, carbonate $\left(\mathrm{CO}_{3}{ }^{2-}\right)$, phosphate $\left(\mathrm{PO}_{4}{ }^{3-}\right)$, silicate $\left(\mathrm{SiO}_{3}{ }^{2-}\right)$, bicarbonate $\left(\mathrm{HCO}_{3}{ }^{-}\right)$ ions were also observed on the adsorption of As contamination by Hoshi and Shikarap ores.

\section{Material and Methods Iron Ores}

The reagents used during the experimental work were sodium meta arsenite, potassium arsenate monobasic, sodium hydroxide, hydrochloric acid, sodium phosphate, sodium carbonate, sodium bicarbonate and sodium sulphate were purchased from Sigma Aldrich, USA. Sulfuric acid was purchased from RCI Labscan Ltd., Thailand and Sodium borohydride was purchased from AppliChem, Germany. The gases used in atomic absorption spectrometer i.e. acetylene and argon were purchased from BOC, Karachi. All the laboratory grade chemicals were used in this study.

Pakistan rich in minerals such are iron ores, coal, gold, copper, chromite, salt, and others. Iron ore samples were obtained from the areas located in Balochistan and Sindh provinces, Pakistan. Hoshi and Shikarap ores are used in the experimental work. Location map of study site Hoshi and Shikarap from Qalat district, Balochistan, Pakistan is shown in Fig. 1.

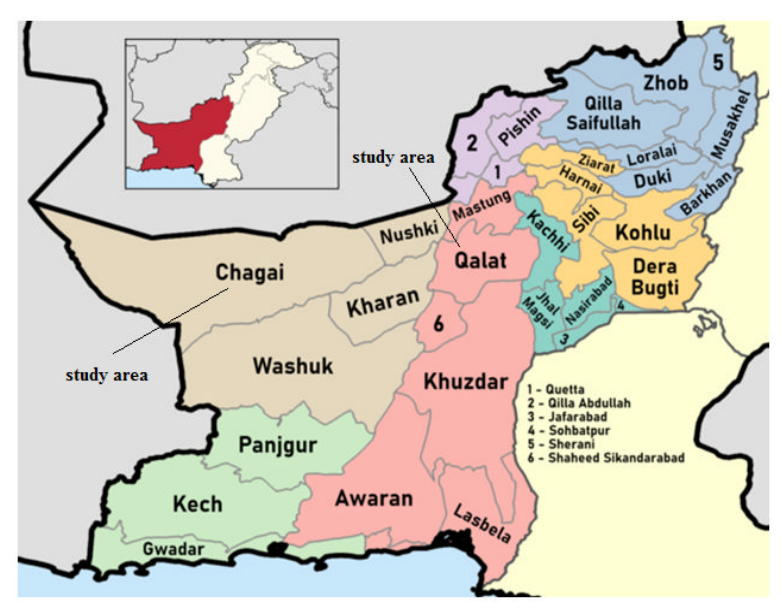

Figure 1. Location map of study site Hoshi and Shikarap from Qalat district, Balochistan, Pakistan 
These sites contain huge deposits of iron ores which are being used in steel manufacture industries. Dalbadin range in district Chagi, Balochistan contain 165 million tons of iron ores which reserves worth of $\$ 4.1$ billion were found at Chiniot-Rajua Saddat, in Punjab province recently which can supply it for 30 to 40 years to a steel mill of 1 million ton capacity [11].

\section{Iron Ore Adsorbent Preparation}

Jaw crusher was used for the size reduction of selected iron ore lumps. Further size reduction was done using brown crusher. Samples were sieved for obtaining $600 \mu \mathrm{m}$ size. The sieved samples were washed using deionized water for the removal of impurities from iron ore particles and then dried at $105^{\circ} \mathrm{C}$. Plastic bottles were utilized for dried sample storage to carry out further experiments.

\section{Batch Adsorption Experiments}

The iron ores have been studied in other parts of the world [9, 12, 13] and the novelty behind this work is that it is the first time ever to use indigenous iron ores of Pakistan in research work for the potential treatment of As contamination from drinking impure water. Before this study, iron ores were only used in steel manufacturing industries in Pakistan. Analytical grade chemical was used in this study without any further purification. High-quality doubledeionized water (Elgastat, Micromeg Deioniser, United Kingdom) was used to make solutions. All the plastic bottles and glass-wares were soaked in the detergent solution, to clean potentially adsorbed impurities on the walls of glass and plastic walls, then in $2 \%$ hydrochloric acid $(\mathrm{HCl})$ solution and in deionized water for at least 1 day. All the apparatus were cleaned with deionized water before use. Different buffer solution of 4,7 and 10 were used for $\mathrm{pH}$ electrode calibration. The batch reaction system was employed for the experimental study of adsorption of As contaminants samples [14]. Atomic absorption spectrometer (AAnalyst - 700) with $193.7 \mathrm{~nm}$ wavelength was used for the As analysis [7, 15].

The As absorbance difference was determined using the initial and final values of the As solution. Equation (1) was used for the calculation of As adsorption percentage.

$$
\text { As } \%=\frac{C_{i}-C_{f}}{C_{i}} \times 100
$$

$C_{i}$ shows initial As concentration, whereas $C_{f}$ represents the final concentration of As. The experiments were repeated thrice in order to find accuracy in results. The deviation in observed results was in the range of $\pm 5 \%$ in the replicated experimental data.

\section{Anions Impact on As(III) and As(V) Adsorption}

In laboratory research normally synthetic water couple with single-ion scheme is used during As adsorption experiments. But, in reality, As is mostly accompanied by other anions such as $\mathrm{Cl}^{1-}, \mathrm{SO}_{4}{ }^{2-}, \mathrm{CO}_{3}{ }^{2-}, \mathrm{PO}_{4}{ }^{3-}$, $\mathrm{SiO}_{3}{ }^{2-}$, and $\mathrm{HCO}_{3}{ }^{-}$. The under groundwater consist of a mixture of ions which can affect adsorption and interfere with each other [16]. The impact of different anions which are chloride $\left(\mathrm{Cl}^{1-}\right)$, Carbonate $\left(\mathrm{CO}_{3}{ }^{2-}\right)$, Phosphate $\left(\mathrm{PO}_{4}{ }^{3-}\right)$, Bicarbonate $\left(\mathrm{HCO}_{3}{ }^{-}\right)$, Silicate $\left(\mathrm{SiO}_{3}{ }^{2-}\right)$ and Sulfate $\left(\mathrm{SO}_{4}{ }^{2-}\right)$ was examined on AS contamination removal by Shikarap and Hoshi ores. For stock solution preparation distilled water was used for each compound making 
$1000 \mathrm{mg} / \mathrm{L}$ concentration. Various ranges of anions concentrations couple with As contaminates were used for the preparation of sample solutions. Such as; $1 \mathrm{~mL}$ of sodium chloride $(\mathrm{NaCl})$ was added in a $50 \mathrm{~mL}$ bottle, after that $2.5 \mathrm{~mL}$ As was introduced in the volumetric bottle then buffer solution quantity of $46 \mathrm{~mL}$ was added in order to prepare a 50 $\mathrm{mL}$ solution. The weight of iron ore was taken $0.5 \mathrm{gm}$. the prepared solution was placed on a shaking machine, and the shaking rpm were controlled at $150 \mathrm{rpm}$ for $2 \mathrm{~h}$. Filteration was done through Whatman filter paper No.42 for the filtration of particles of iron ore for further analysis through atomic absorption spectrometer.

\section{Results and Discussion Adsorption Study of As(III) and As(V)}

As(III) and $\mathrm{As}(\mathrm{V})$ were examined to check the As removal percentage from samples of Shikarap and Hoshi ore shown in Fig. 2. The adsorption of As(III) was accomplished with dose of adsorbent $0.5 \mathrm{~g} / 50$ $\mathrm{mL}$, initial As(III) concentration of $50 \mu \mathrm{g} / \mathrm{L}$, $\mathrm{pH} 6$, shaking of sample was done for $2 \mathrm{~h}$ at $150 \mathrm{rpm}$. The adsorption of $\mathrm{As}(\mathrm{V})$ was performed with an adsorbent dosage of 0.75 $\mathrm{g} / 50 \mathrm{~mL}, \mathrm{pH} 7, \mathrm{As}(\mathrm{V})$ initial concentration of $50 \mu \mathrm{g} / \mathrm{L}$, and $150 \mathrm{rpm}$. The results reveal that samples of Hoshi ore gave greater adsorption for $\mathrm{As}(\mathrm{III})$ and $\mathrm{As}(\mathrm{V}) 82 \%$ and $77 \%$ among all selected samples. The next higher adsorption for $\mathrm{As}(\mathrm{V})$ and As (III) was of Shikarap ore samples $64 \%$ and $58 \%$, respectively. The Dilband and Qalat samples portrayed the next higher adsorption values of $56 \%$ and $54 \%$ for $\mathrm{As}(\mathrm{V})$ and $42 \%$ and $52 \%$ for As(III), respectively. The order of adsorption percentage in $\operatorname{As}(\mathrm{V})$ is Hoshi > Shikarap > Qalat $>$ Dilband $>$ Sohneri $>$ Chagi. The order of adsorption percentage in As(III) is Hoshi > Shikarap > Qalat > Dilband > Chagi > Sohneri. Because the adsorption percentage of
Hoshi and Shikarap is higher than the other iron ore samples for both As(III) and As(V), therefore Shikarap and Hoshi were selected to carry out further experiments.

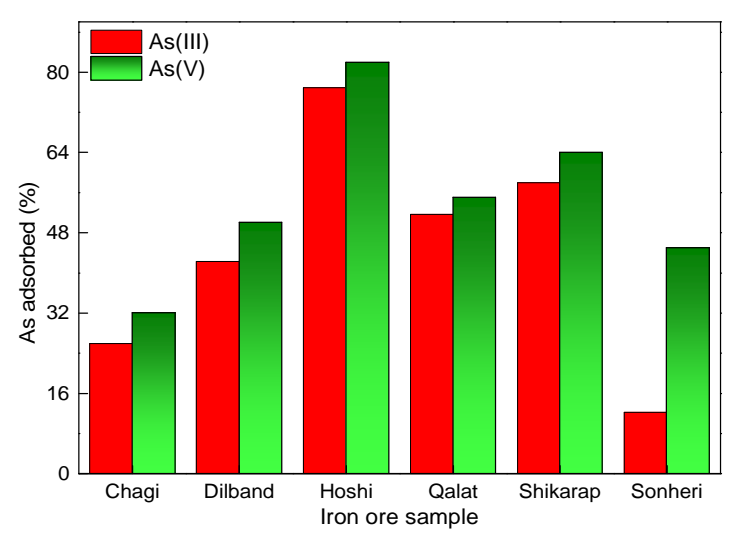

Figure 2. As(V) and As(III) adsorption on iron ore samples of selected locations

\section{Impact of pH on As(III) and As(V)}

Fig. 3 depicting the $\mathrm{pH}$ effect on Shikarap and Hoshi ore samples from As contamination. Hoshi and Shikarap samples in As(III) gave higher adsorption percentage at pH 6 i.e. $75 \%$ and $70 \%$, respectively. Whereas in As(V) Shikarap and Hoshi samples showed the highest adsorption percentage at $\mathrm{pH} 7$ i.e. $84 \%$ and $80 \%$, respectively. Therefore, $\mathrm{pH} 6$ and $\mathrm{pH} 7$ were optimized for adsorption of As contaminates on iron ore respectively for further experiment. It was found that beyond pH 7 the removal of As(III) decreases with the lowest adsorption of Shikarap (20\%) at $\mathrm{pH} 8$. The results were in good agreement with the study [17], concluded that at $\mathrm{pH} 7$ the highest adsorption of $\mathrm{As}(\mathrm{III})$ for hematite takes place. While above pH 7 adversely effects on adsorption efficiency. Fig. 3 also revealed that adsorption of $\mathrm{As}(\mathrm{V})$ was higher at $\mathrm{pH}$ ranges $6<\mathrm{pH}<7$, and this is in relation to a study [18]. As $(\mathrm{V})$ has several substances in an aqueous environment, which depend on the $\mathrm{pH}$ of the solution. Arsenate $\left(\mathrm{AsO}_{4}{ }^{3-}\right)$, dihydrogen arsenate $\left(\mathrm{H}_{2} \mathrm{AsO}_{4}{ }^{-}\right)$, arsenic acid $\left(\mathrm{H}_{3} \mathrm{AsO}_{4}\right)$ 
and hydrogen arsenate $\left(\mathrm{HAsO}_{4}{ }^{2-}\right)$, are the main $\mathrm{As}(\mathrm{V})$ constituent for the $\mathrm{pH}$ of less than $2.18,6.65,6.65-11.19$, and greater than 11.19 respectively [19].

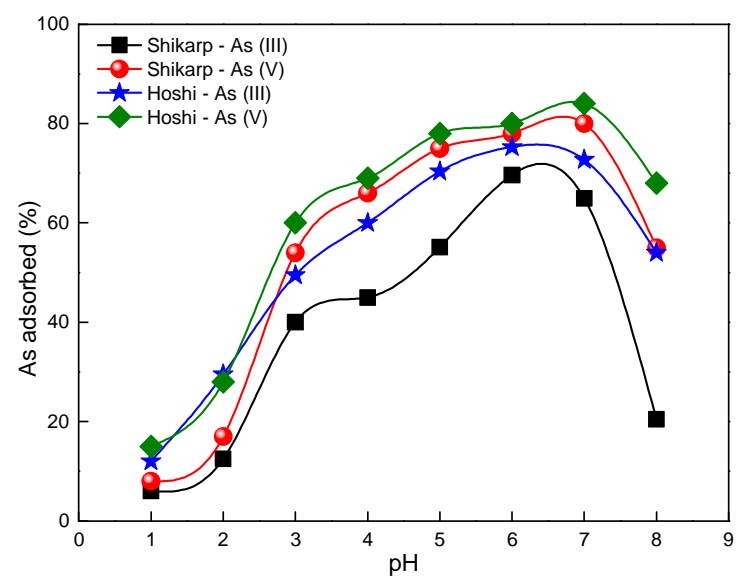

Figure 3. $\mathrm{pH}$ effect on $\mathrm{As}(\mathrm{III})$ and $\mathrm{As}(\mathrm{V})$ concentration

\section{Impact of Adsorbent Dose on As(III) and $\operatorname{As}(V)$}

Impact of Hoshi and Shikarap ore dose were observed via varying the adsorbent from 0.125 to 1.25 for $\mathrm{As}(\mathrm{III})$ and for $\mathrm{As}(\mathrm{V})$ from $0.1 \mathrm{~g}$ to $1.0 \mathrm{~g}$ which are presented in Fig. 4. The As(III) uptake increased as dose of iron ore from $0.25 \mathrm{~g}$ to $0.5 \mathrm{~g}$ was increased and the highest adsorption $72 \%$ for As(III) was achieved at $0.5 \mathrm{~g}$. Hence $0.5 \mathrm{~g}$ adsorbent was optimized for further adsorption study of As(III).

The Hoshi and Shikarap samples adsorb $81 \%$ and $74 \%$ of $\mathrm{As}(\mathrm{V})$, respectively at the dosage of $0.75 \mathrm{~g}$ and the As removal declined at a higher dose of $1.0 \mathrm{~g}$ for each Hoshi and Shikarap samples. Thus, $0.75 \mathrm{~g}$ adsorbent dose was optimized for $\mathrm{As}(\mathrm{V})$ adsorption to carried out further study. A study conducted by Podder [20] observed the impact of adsorbent dose and found that an increase in the dose of adsorbent shows speedy rise in adsorption of As contaminant. This may be described as throughout the adsorption procedure due to the accessibility of larger surface area, the adsorption sites remained unsaturated. With the increase in the adsorbent amount, the accessible sites present for adsorption increase. Although the amount of adsorption dose increases, many active sites per unit volume of solution increase, that results in an increase in As contaminates removal $\%$. The further rise in adsorbent dose greater than $0.56 \mathrm{~g}$ for $\mathrm{As}(\mathrm{III})$ and greater than $0.76 \mathrm{~g}$ for $\mathrm{As}(\mathrm{V})$ decreased the adsorption slightly. It could be because of the fact that the higher adsorbent dose can produce a screen effect on the surface of the adsorbent, preventing the binding sites and thus decreasing the As(III) and $\mathrm{As}(\mathrm{V})$ adsorption.

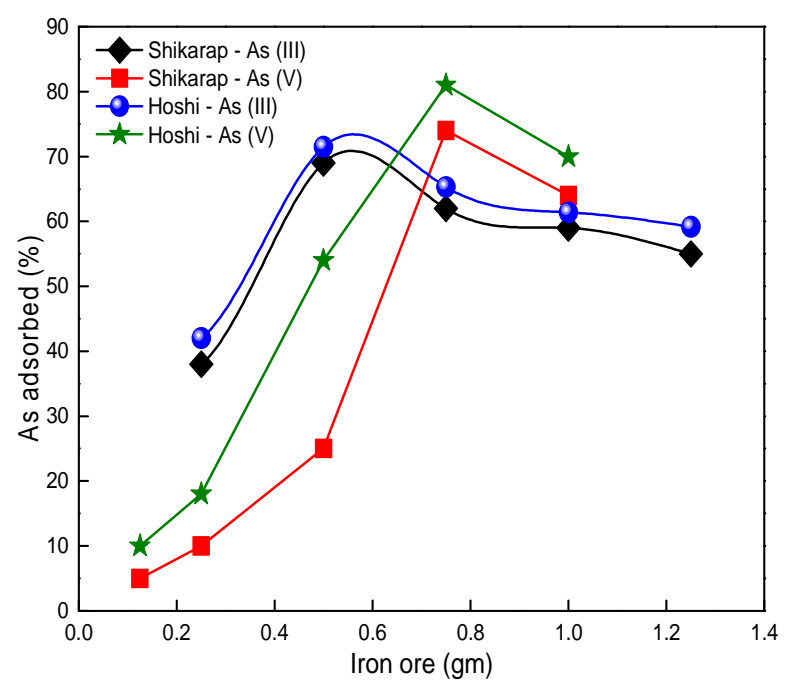

Figure 4. Adsorbent dose impact on $\mathrm{As}(\mathrm{V})$ and $\mathrm{As}(\mathrm{III})$ removal

\section{Impact of Contact Time}

To find out the efficacy of adsorption, the adsorption equilibria analysis is necessary to be carried out. The contact time effect (30$240 \mathrm{~min}$ with a step size of $30 \mathrm{~min}$ ) was carried out with As contaminants adsorption on Shikarap and Hoshi ores as presented in Fig. 5. The time for agitation was differed between 30 to 240 min with a step size of 30 min keeping initial $\mathrm{As}(\mathrm{III})$ and $\mathrm{As}(\mathrm{V})$ concentration $50 \mu \mathrm{g} / \mathrm{L}, 0.5 \mathrm{~g}$ and $0.75 \mathrm{~g}$ of 
adsorbents, respectively and $150 \mathrm{rpm}$ shaking speed. The appraisal of Fig. 5 revealed that As contaminants adsorption percentage is directly proportional to the agitation time rise and the highest adsorption of As contamination is attained at $2 \mathrm{~h}$ agitation. These results is consistent with the findings of past studies by Kundu et al., [21], in which the researchers observed the ideal agitation time of 120 minutes. The adsorption of As contamination was increasing in the initial $90 \mathrm{~min}$ until the equilibrium was observed at agitation time of $120 \mathrm{~min}$. The Hoshi and Shikarap presented comparatively higher adsorption of $83.4 \%$ and $79 \%$ for $\mathrm{As}(\mathrm{V})$ at $2 \mathrm{~h}$, respectively. But lower As(III) removal of $73 \%$ was observed by Hoshi and $65 \%$ by Shikarap ore. These results are in agreement with the study conducted by Gibbons and Gagnon that because iron (III) oxides $\left(\mathrm{Fe}_{2} \mathrm{O}_{3}\right)$ displayed greater adsorption capacity concerning $\mathrm{As}(\mathrm{V})$ than aluminum oxides, and were effective adsorbents during dealing with As(III) species [22].

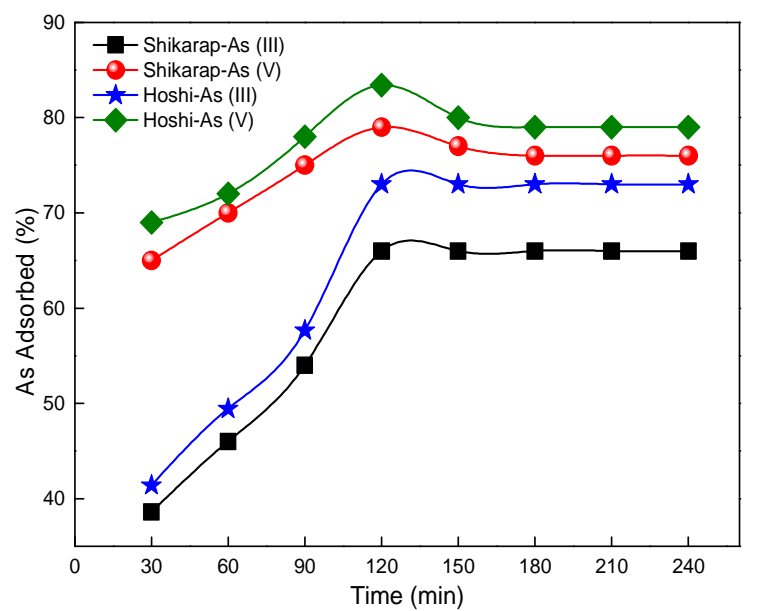

Figure 5. Contact time influence on $\mathrm{As}(\mathrm{III})$ and $\mathrm{As}(\mathrm{V})$ adsorption

\section{Influence of Shaking Speed}

Shaking speed (rpm) impact was scrutinized via differing the speed between 50 to $200 \mathrm{rpm}$ for As contaminants samples. As(III) samples were made by taking $50 \mu \mathrm{g} / \mathrm{L}$ of initial concentration with $\mathrm{pH} 6$ buffer to make $50 \mathrm{~mL}$ solution and then $0.5 \mathrm{~g}$ of adsorbent was added in it. The maximum adsorption rate was obtained for As(III) at $73 \%$ by Hoshi ore, while the Shikarap ore adsorbs comparatively lower $62 \%$ at $150 \mathrm{rpm}$ as illustrated in Fig. 6. The better efficiency was observed up to $150 \mathrm{rpm}$, while it decreased above $150 \mathrm{rpm}$ up to 175 for As(III). As(V) samples were made by taking $50 \mu \mathrm{g} / \mathrm{L}$ of initial concentration with $\mathrm{pH} 7$ buffer to make $50 \mathrm{~mL}$ solution and then $0.75 \mathrm{~g}$ of adsorbent was added in it. At shaking speed $150 \mathrm{rpm}$, Hoshi ore samples gave the best results of $\mathrm{As}(\mathrm{V})$ adsorption about $78 \%$ and comparatively lower $69 \%$ for As(V). The Ascontamination adsorption percent increased from 50 to $150 \mathrm{rpm}$ and then gradually decreased. The optimal $150 \mathrm{rpm}$ offered better results for both As contaminates. Hence, 150 rpm was set for further experimental work.

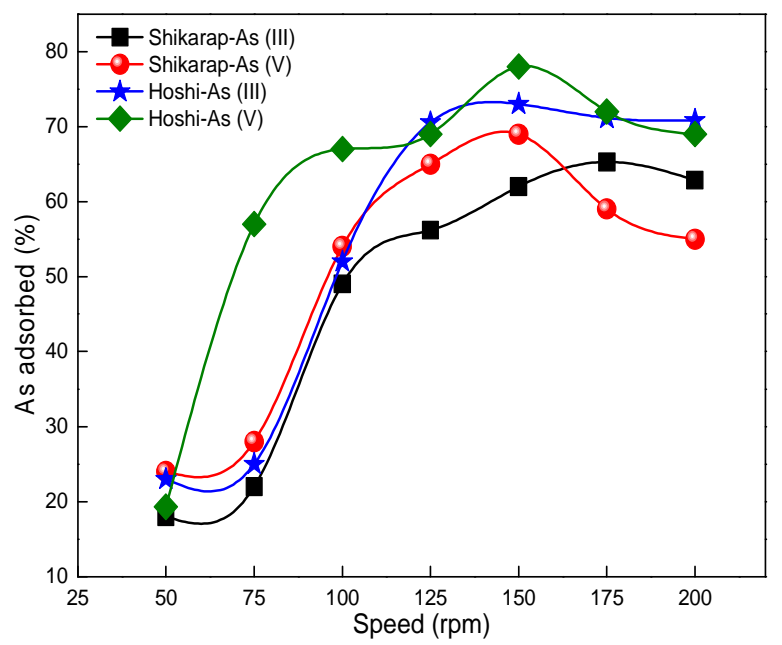

Figure 6. Impact of shaking speed (rpm) on \% adsorbed arsenic by iron ore Interfering Effect of Anions on Adsorption
of $A s(I I I)$ and $A s(V)$

The interfering impact of common anions on the As contaminates adsorption by iron ores of Hoshi and Shikarap with aqueous solutions are discussed below. 
Fig. 7 presents the impact of sodium bicarbonate on As contamination adsorption. Samples for adsorption of As were prepared as; without sodium bicarbonate, with 100 $\mathrm{mg} / \mathrm{L} \quad \mathrm{NaHCO}_{3}$ and $1000 \mathrm{mg} / \mathrm{L} \mathrm{NaHCO}_{3}$. Fig. 7 shows that as the $\mathrm{NaHCO}_{3}$ concentration in $\mathrm{mg} / \mathrm{L}$ increases the As removal by As contamination decreased by Shikarap and Hoshi ores. The impact of bicarbonate by iron(III) hydroxide has been highlighted and proved that the As(III) adsorption has been declined at lower surface site coverage and fewer concentrations [23].

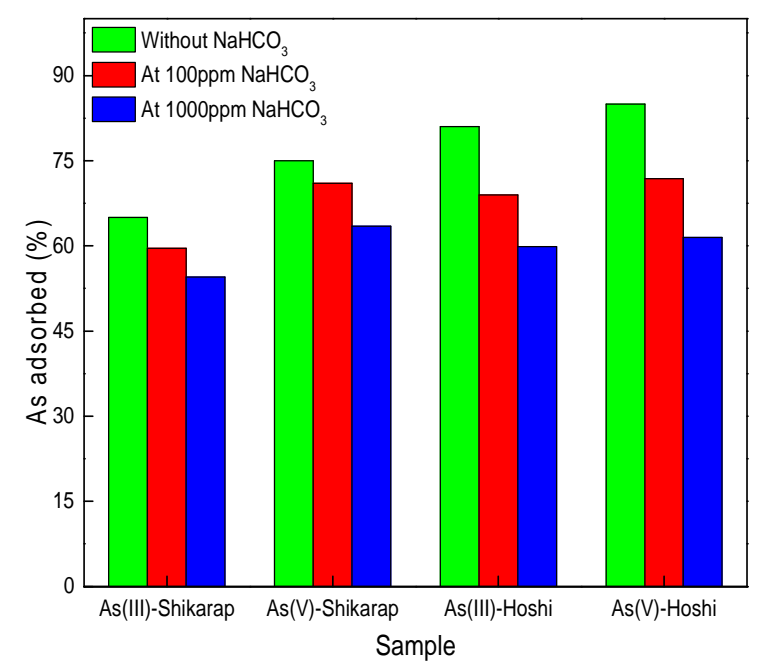

Figure 7. Impact of sodium bicarbonate on the removal of As(III) and $\operatorname{As}(\mathbf{V})$

Fig. 8 reveals that Hoshi iron ore without sodium carbonate yields higher adsorption as compared to the samples with $100 \mathrm{mg} / \mathrm{L}$ and $1000 \mathrm{mg} / \mathrm{L}$ sodium carbonate in both $\mathrm{As}(\mathrm{III})$ and $\mathrm{As}(\mathrm{V})$. This proves that sodium carbonate anions cause hindrance resulting in lower adsorption by iron ore. According to a study, adsorption of As contamination with ferric hydroxide is negligibly affected by carbonate [24]. Another research shows that $\left(\mathrm{CO}_{3}{ }^{2-}\right)$ and bicarbonate may be adsorbed on ferric oxides by developing bonded electron surface complexes with $\mathrm{Fe}(\mathrm{OH})_{3}$ and therefore decreasing As adsorption by iron ores [25].

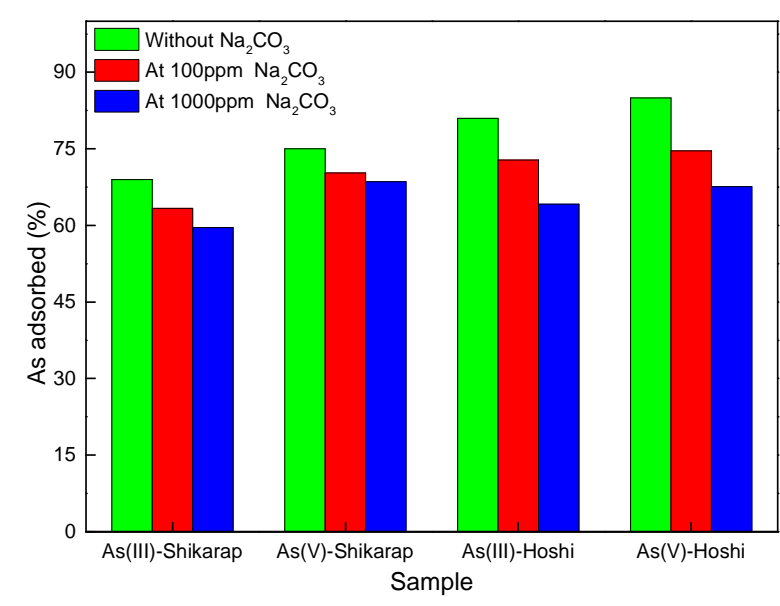

Figure 8. Impact of sodium carbonate on the removal of As(III) and $\mathrm{As}(\mathrm{V})$

The Hoshi sample exhibited higher percentages of adsorption with both As(III) and $\mathrm{As}(\mathrm{V})$ than Shikarap sample as demonstrated in Fig. 9 subsequently with adding of $100 \mathrm{mg} / \mathrm{L} \quad \mathrm{NaCl}$ adsorption decreased which further slightly decreased with the addition of $\mathrm{NaCl}$ concentration of $1000 \mathrm{mg} / \mathrm{L}$ in both Hoshi and Shikarap.

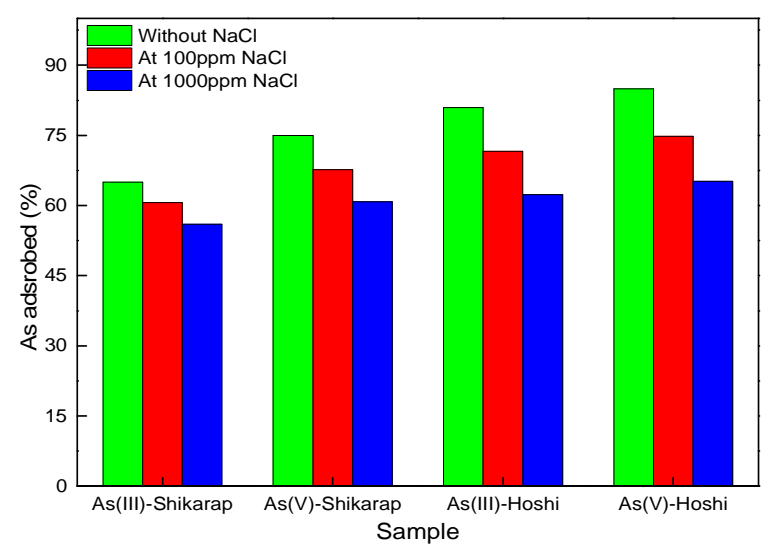

Figure 9. Impact of sodium chloride on the removal of As(III) and $\mathbf{A s}(\mathbf{V})$

Indeed, the rejection of $\mathrm{As}(\mathrm{V})$ is reduced in the existence of $\mathrm{NaCl}$. This outcome is well-known to membranes in which Donnan (charge) discharge performs a vital role due to the charge exclusion is reduced as salt concentration in the test solution rises, thereby reducing the repellency of the charge $\mathrm{As}(\mathrm{V})$ oxyanion [26]. 
Fig. 10 illustrates that Hoshi ore exhibited the highest adsorption of $85 \%$ for As $(\mathrm{V})$ without sodium phosphate dibasic and $83 \%$ for As(III). But then the adsorption decreases gradually at $100 \mathrm{mg} / \mathrm{L}$ and 1000 $\mathrm{mg} / \mathrm{L}$ for both As(V) and As(III) with Hoshi ore illustrating the negative effects of phosphate ions on As removal. Shikarap ore for $\mathrm{As}(\mathrm{V})$ adsorbs $75 \%$ without sodium phosphate dibasic and 67\% adsorption for As(III) without sodium phosphate dibasic. These results showed that Hoshi ore adsorb more As than Shikarap ore without sodium phosphate dibasic but in the presence of $\left(\mathrm{Na}_{2} \mathrm{HPO}_{4}\right)$ both ores showed a decline in adsorption.

The phosphate ions have the strong attraction for iron oxides by creating innersphere complexes and contend for same bonding sites with As and thus retard the As removal efficiency by hematite $\left(\mathrm{Fe}_{2} \mathrm{O}_{3}\right)$ as shown in Fig. 10 [25].

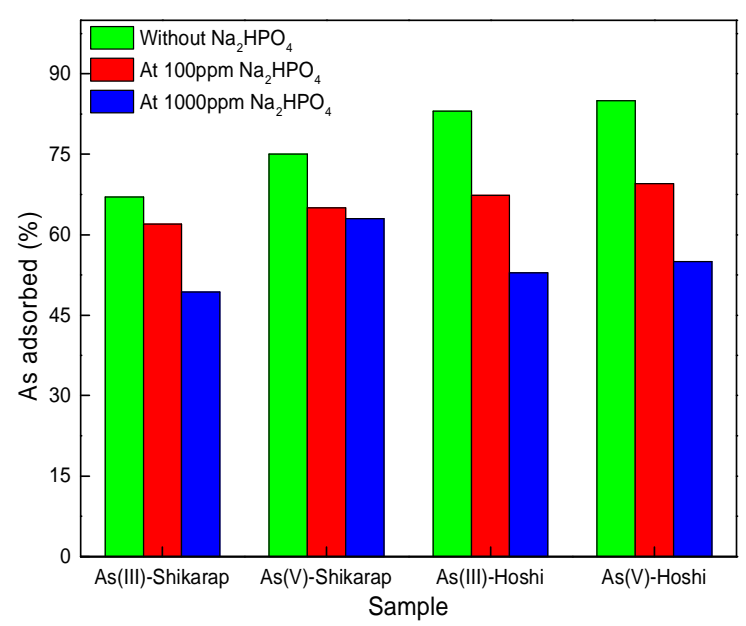

Figure 10. Impact of sodium phosphate dibasic on the removal of As(III) and $\operatorname{As}($ V)

Sodium silicate $\left(\mathrm{Na}_{2} \mathrm{SiO}_{3}\right)$ puts bad impact on $\mathrm{As}(\mathrm{III})$ and $\mathrm{As}(\mathrm{V})$ adsorption via Hoshi ore at $100 \mathrm{mg} / \mathrm{L}$ and $1000 \mathrm{mg} / \mathrm{L}$ by decreasing the removal from $85 \%$ without $\mathrm{Na}_{2} \mathrm{SiO}_{3}$ to below $75 \%$ as presented in Fig. 11 . Shikarap ore even exhibited lower adsorption as compared to Hoshi. Shikarap ore with sodium silicate at $100 \mathrm{mg} / \mathrm{L}$ adsorbs $62 \%$ As(III) and at $1000 \mathrm{mg} / \mathrm{L}$ adsorb 52\% As(III). Shikarap ore $\mathrm{As}(\mathrm{V})$ adsorption decreases from $75 \%$ without sodium silicate to $70 \%$ at 100 $\mathrm{mg} / \mathrm{L}$ and even lower adsorption of $65 \%$ at a elevated concentration of $1000 \mathrm{mg} / \mathrm{L}$.

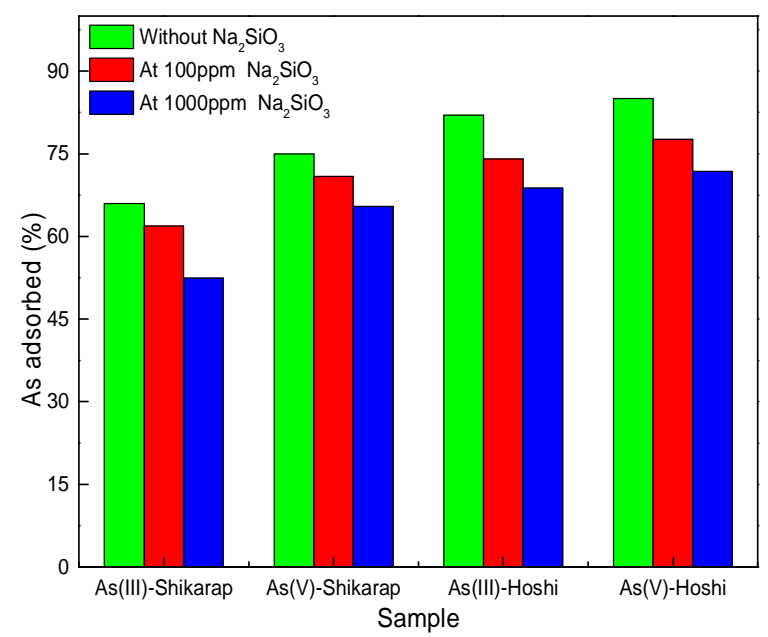

Figure 11. Impact of sodium silicate on the removal of As(III) and $\operatorname{As}(\mathbf{V})$

Fig. 12 demonstrates that sodium sulfate also decreases $\mathrm{As}(\mathrm{III})$ and $\mathrm{As}(\mathrm{V})$ elimination via both ores at $100 \mathrm{mg} / \mathrm{L}$ and $1000 \mathrm{mg} / \mathrm{L}$ concentrations as compared to samples deprived of sodium sulfate. This indicates the interference conduct of sulfate ions on As(III) adsorption. The Shikarap sample deprived of $\mathrm{Na}_{2} \mathrm{SO}_{4}$ shows lower As (III) and As (V) adsorption than the Hoshi sample. The same behavior was also discussed in the study of the adverse impact of sulfate ions on As adsorption of iron ore (hematite) [27]. In another study, researchers investigated that the adsorption of $\mathrm{As}(\mathrm{III})$ and $\mathrm{As}(\mathrm{V})$ on aqueous ferric oxide decreases in the existence of sulfates with a $\mathrm{pH}$ of 4-7 [28, 29].

The order of interference of cations and anions experimented on $\mathrm{As}(\mathrm{III})$ and $\mathrm{As}(\mathrm{V})$ adsorption reported in the study [30] is phosphate $>$ sulfate $>$ silicate. The contending consequences of ions on the adsorption of As(III) declined as: phosphate > silicate > bicarbonate $>$ chloride $>$ carbonate $>$ sulfate 
which is notified by [23]. On the contrary, the order of the interfering impact of ions on the adsorption of $\mathrm{As}(\mathrm{V})$ is phosphate > bicarbonate $>$ chloride $>$ carbonate $>$ silicate $>$ sulfate.

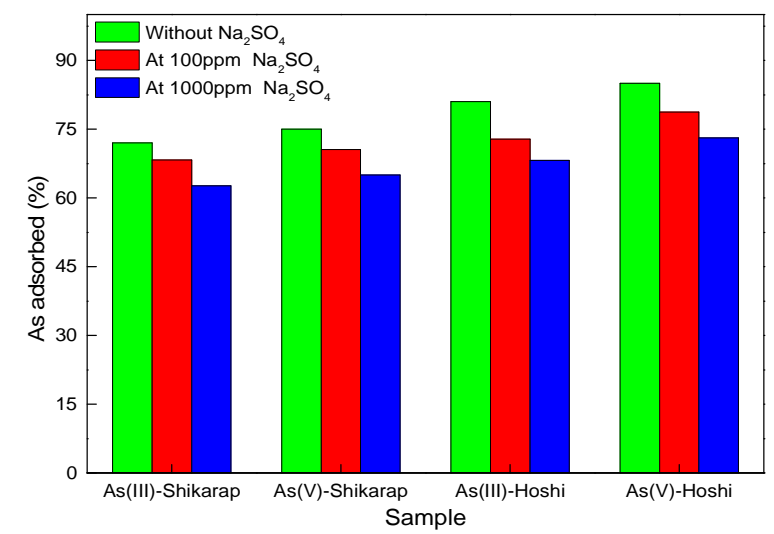

Figure 12. Sodium sulphate $\left(\mathrm{Na}_{2} \mathrm{SO}_{4}\right)$ impact on the removal of $\mathrm{As}(\mathrm{III})$ and $\mathrm{As}(\mathrm{V})$

\section{Conclusion}

This work shows that indigenous iron ores of Hoshi, Shikarap located in Balochistan are potential adsorbent for the deletion of carcinogenic As(III) and As(V). There are huge deposits of iron ores in Pakistan and these can be efficient and economical for the cure of As contaminated water as adsorbents. The results showed that Hoshi ore sample gave the highest adsorption for $\mathrm{As}(\mathrm{V})$ and As(III) i.e. $82 \%$ and $77 \%$, respectively among the all iron ore samples. But the other ores are also competent adsorbent for As treatment and could be used in continuous water flow column filters. It was obvious from adsorption study that all the six iron ores samples used exhibited higher removal \% towards $\mathrm{As}(\mathrm{V})$ as compared to As(III). The optimized parameters for As(III) concluded were as; $\mathrm{pH}$ 6 , a dose of adsorbent $0.5 \mathrm{~g}$, contact time 120 min and agitation speed $150 \mathrm{rpm}$. The bestachieved parameters for $\mathrm{As}(\mathrm{V})$ were found as; $\mathrm{pH} 7,0.75 \mathrm{~g}$ adsorbent dose, contact time 120 min and shaking time $150 \mathrm{rpm}$. These indigenous iron ores have proved efficient and economical adsorbent for the exclusion of
$\mathrm{As}(\mathrm{III})$ and $\mathrm{As}(\mathrm{V})$. It is further recommended that these ores could be used as promising adsorbents in water treatment filters in arsenic affected areas so the common people can easily afford. The common people can get benefit from these iron ore built filters and prevent themselves from deadly diseases including Cancer, Cardiovascular and brain. It was observed that all the anions i.e., sodium bicarbonate, sodium carbonate, sodium chloride, sodium phosphate, sodium silicate and sodium sulfate decreased the As(III), As $(V)$ adsorption by Hoshi and Shikarap ore samples. These anions affect negatively by reducing the adsorption of As(III) and As(V) when compared with samples without anions.

The Government, NGO's, industries should focus on the manufacturing and installation of indigenous iron ores water filters in As affected areas for the sake of health and safety of people.

\section{Acknowledgments}

This work was endorsed by the PakUS Science and Technology Cooperation Program and Higher Education Commission (HEC) Pakistan.

\section{References}

1. T. G. Kazi, Brahman, J. A. Baig and H. I. Afridi, J. Hazard. Mater., 375 (2018) 159.

doi: 10.1016/j.jhazmat.2018.05.069

2. A. Shahab, S. Qi and M. Zaheer, Environ. Sci. Pollut. Res., 26 (2019) 30642. doi: 10.1007/s11356-018-2320-8

3. Z. Bhatti, K. Qureshi, I. Bhatti, I. N. Unar, and M. Y. Khuhawar, Mehran Univ. Res. J. Eng. Technol., 36 (2017) 1037. doi: $10.22581 /$ muet 1982.1704 .28

4. I. Ali, Chem. Rev., 112 (2012) 5073. 
doi: $10.1021 / \mathrm{cr} 300133 \mathrm{~d}$

5. I. Ali, M. Asim, and T. A. Khan, J. Environ. Manage., 113 (2012) 170. doi:10.1016/j.jenvman.2012.08.028

6. Z. A. Bhatti, K. Qureshi, M. Y. Khuhawar, A. W. Bhutto, Z. A. Solangi, and I. N. Unar, Int. J. Res. Rev. Appl. Sci., 34 (2018) 66.

7. H. Guo, D. Stüben, Z. Berner, and U. Kramar, J. Hazard. Mater., 151 (2018) 628.

doi: 10.1016/j.jhazmat.2007.06.035

8. S. K. R. Yadanaparthi, D. Graybill and R. von Wandruszka, J. Hazard. Mater., 171 (2009) 1.

doi: 10.1016/j.jhazmat.2009.05.103

9. W. Zhang, P. Singh, E. Paling, and S. Delides, Miner. Eng., 17 (2004) 517. doi: 10.1016/i.mineng.2003.11.020

10. J. A. Baig, T. G. Kazi, M. B. Arain, H. I., Afridi, G. A. Kandhro, R. A. Sarfraz, M. K. Jamali and A. Q. Shah, J. Hazard. Mater., 166 (2009) 662.

doi: 10.1016/j.jhazmat.2008.11.069

11. K. Mustafa, in The News, ed. Islamabad, (2018).

12. S. Chatterjee and S. De, Sep. Purif. Tech., 179 (2017) 357.

doi: 10.1016/j.seppur.2017.02.019

13. A. Maiti, B. K. Thakur, J. K. Basu and S. De, J. Hazard. Mater., 262 (2012) 1176.

doi: 10.1016/j.jhazmat.2012.06.036

14. Q. L. Zhang, Y. Lin, X. Chen and N. Y. Gao, J. Hazard Mater., 148 (2007) 671. doi: 10.1016/j.jhazmat.2007.03.026

15. P. K. Neghlani, M. Rafizadeh and F. A. Taromi, J. Hazard Mater., 186 (2011) 182.

doi: 10.1016/j.jhazmat.2010.10.121.

16. V. Uwamariya, IHE Delft Institute for Water Education, (2013). doi: $10.1021 / 1 a 0499214$

17. C. Su, and R. W. Puls, Environ. Sci. Technol., 35 (2001) 1487. doi: $10.1021 / \mathrm{es} 001607 \mathrm{i}$
18. Y.-h. Xu, T. Nakajima and A. Ohki, J. Hazard. Mater., 92 (2002) 275. doi: 10.1016/S0304-3894(02)00020-1

19. T. Su, X. Guan, Y. Tang, G. Gu and J. Wang, J. Hazard Mater., 176 (2010) 466.

doi: 10.1016/j.jhazmat.2009.11.052

20. M. Podder and C. Majumder, J. Mol. Liq., 212 (2015) 382.

doi: 10.1016/j.molliq.2015.09.011

21. S. Kundu and A. Gupta, J. Hazard. Mater., 142 (2007) 97.

doi: 10.1016/j.jhazmat.2006.07.059

22. M. K. Gibbons and G. A. Gagnon, $J$. Hazard Mater., 186 (2011) 1916. doi: 10.1016/j.jhazmat.2010.12.085

23. X. Meng, G. P. Korfiatis, S. Bang and K. W. Bang, Toxicol. Lett., 133 (2002) 103.

doi: 10.1016/S0378-4274(02)00080-2

24. X. Meng, S. Bang and G. P. Korfiatis, Water Res., 34 (2000) 1255. doi: 10.1016/S0043-1354(99)00272-9

25. X. Lv, Y. Hu, J. Tang, T. Sheng, G. Jiang, and X. Xu, Chem. Eng. J., 218 (2013) 55 . doi: 10.1016/j.cej.2012.12.026

26. A. Seidel, J. J. Waypa and M. Elimelech, Environ. Eng. Sci., 18 (2001) 105. doi: 10.1089/10928750151132311

27. N. Randhawa, N. Murmu, S. Tudu and D. Sau, Environ. Chem. Lett., 12 (2014) 517.

doi: 10.1007/s10311-014-0477-z

28. J. A. Wilkie and J. G. Hering, Colloid. Surf. A, 107 (1996) 97. doi: 10.1016/0927-7757(95)03368-8

29. A. Jain and R. H. Loeppert, J. Environ. Qual., 29 (2000) 1422. doi:10.2134/jeq2000.004724250029000 $\underline{50008 x}$

30. A. Gupta, V. S. Chauhan and N. Sankar Arama Krishnan, Water Res., 43 (2009) 3862.

doi:doi.org/10.1016/j.watres.2009.05.040 